\title{
ZMIANY W WYDATKACH NA DZIALALNOŚĆ BADAWCZO-ROZWOJOWĄ W KRAJACH UNII EUROPEJSKIEJ I PRZEDSIĘBIORSTWACH
}

\begin{abstract}
W wielu obszarach nauki i branżach gospodarki wydatki na działalność badawczorozwojową determinują skalę i poziom badań. Poziom wydatków jest uwarunkowany przez politykę kraju, strategie przedsiębiorstw oraz przez inwestorów. Celem artykułu jest przedstawienie zmian w wydatkach na działalność badawczo-rozwojową w krajach Unii Europejskiej oraz w przedsiębiorstwach, w latach 2010-2014. W analizie porównano początek realizacji strategii Europa 2020 i okres, w którym realizowano strategię lizbońską. Wyniki wskazują na zmiany i zróżnicowanie w podejściu do finansowania działalności badawczo-rozwojowej na poziomie krajów oraz przedsiębiorstw. Różnice widoczne są zarówno w dynamice wzrostu wydatków na $\mathrm{B}+\mathrm{R}$ jak i w strukturze ich finansowania. Nie da się jednak ich wyjaśnić stosując wyłącznie podział według kryterium wartości PKB lub wydatków na $\mathrm{B}+\mathrm{R}$ w badanych krajach. Interesujące różnice można zaobserwować w krajach Grupy Wyszehradzkiej, w której jeszcze niedawno relacja wydatków na B+R do PKB była zbliżona. W niektórych krajach, preferowany jest wzrost finansowania ze środków państwowych, w innych, w tym w Polsce, stymuluje się wzrost wydatków przedsiębiorstw na działalność B+R. Choć trudno jednoznacznie określić, które rozwiązanie okaże się lepsze dla gospodarki i biznesu, wpływ polityki realizowanej w poszczególnych krajach jest wyraźnie widoczny w danych statystycznych. Zmiany w sposobie finansowania działalności badawczo-rozwojowej powinny być obserwowane przez zarząadzających przedsiębiorstwami, ponieważ odmienne podejście do sposobu jej finansowania na poziomie kraju powinno zostać uwzględnione w ich analizach i decyzjach.

Słowa Kluczowe: wydatki, badania, rozwój, przedsiębiorstwa, Europa.
\end{abstract}

\section{WPROWADZENIE}

Wydatki na działalność badawczo-rozwojową tradycyjnie uznaje się za istotny czynnik decydujący o innowacyjności przedsiębiorstw i krajów. Po wielu latach badań stwierdzono, że relacje determinujące poziom wydatków na działalność badawczo-rozwojową mają charakter złożony i zjawisko powinno się badać w wielu wymiarach i z uwzględnieniem interakcji ${ }^{2}$. Celem artykułu jest przedstawienie zmian $\mathrm{w}$ finansowaniu działalności badawczo-rozwojowej w krajach Unii Europejskiej oraz w przedsiębiorstwach w latach 2010-2014. Porównano okres, w którym realizowano strategię lizbońską 2000-2010 oraz początek realizacji strategii Europa 2020. W artykule wykorzystano dane Eurostat oraz projektu The Economics of Industrial Research \& Innovation realizowanego przez Institute for Prospective Technological Studies.

\footnotetext{
${ }^{1}$ Dr Przemysław Pomykalski, Wydział Organizacji i Zarządzania, Politechnika Łódzka, ul. Piotrkowska 266, 90-924 Łódź, e-mail:ppomykalski@gmail.com

${ }^{2}$ B.H. Hall, N. Rosenberg (Eds.). Handbook of the Economics of Innovation, Vol. 1, Elsevier 2010.
} 


\section{ZMIANY W WYDATKACH NA DZIALALNOŚĆ BADAWCZO- -ROZWOJOWĄ W KRAJACH UE}

Przyjęta w 2000 roku strategia lizbońska zakładała, że wydatki na działalność B+R w Unii Europejskiej osiągną 3\% Produktu Krajowego Brutto (PKB). Celu nie osiągnięto w większości krajów Unii i w efekcie również na średniej dla UE (rys. 1). Osiągnięcia 3\% wydatków na działalność B+R stało się ponownie celem Strategii Europa $2020^{3}$.

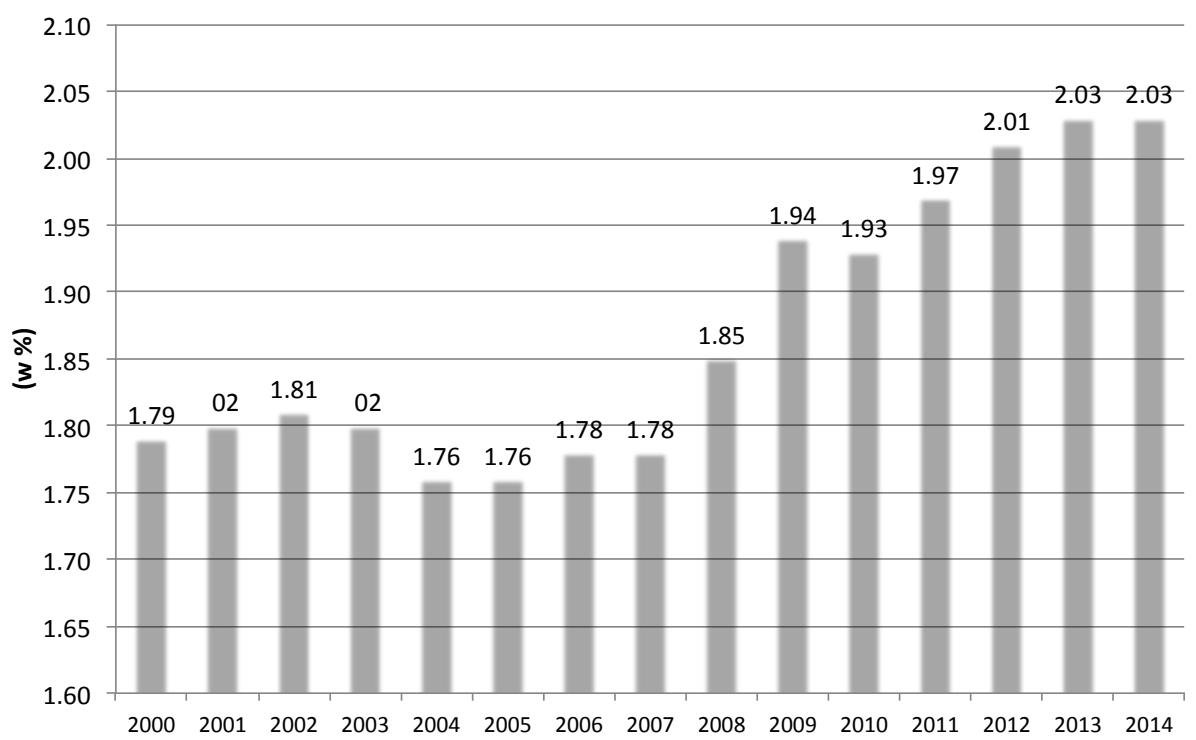

Rys. 1. Wydatki (GERD) na B+R w 28 krajach Unii Europejskiej jako procent PKB

Źródło: opracowanie własne na podstawie danych Eurostat (stan na 1.06.2016 r.).

Zamierzony cel zwiększenia wydatków osiągnięto jedynie w Austrii i w Danii. W Szwecji i w Finlandii wydatki na B+R stanowiły ponad 3\% PKB przed przyjęciem założeń strategii lizbońskiej. W pozostałych krajach wyniki były zróżnicowane i w duży stopniu uzależnione od efektów kryzysu w 2008 roku.

W latach 2010-2014 można zaobserwować interesujące zmiany w Czechach, Polsce, Słowacji i na Węgrzech (rys. 2). Wzrost udziału wydatków na B+R jest ewidentny w krajach Grupy Wyszehradzkiej, jednak skala wzrostu jest zróżnicowana. Czechy nadal są ewidentnym liderem w regionie zarówno w ujęciu udziału wydatków na B+R w PKB, jak i dynamiki ich wzrostu. Niższy niż w Czechach udział, ale podobną dynamikę można zaobserwować na Węgrzech. Polska i Słowacja notują znacznie słabszą dynamikę wzrostu udziału oraz niższy udział wydatków na B+R w PKB.

\footnotetext{
${ }^{3}$ Europa 2020. Strategia na rzecz inteligentnego i zrównoważonego rozwoju sprzyjajaca właczeniu społecznemu, ec.europa.eu/eu2020/pdf/1_PL_ACT_part1_v1.pdf (dostęp: 1.06.2016 r.).
} 


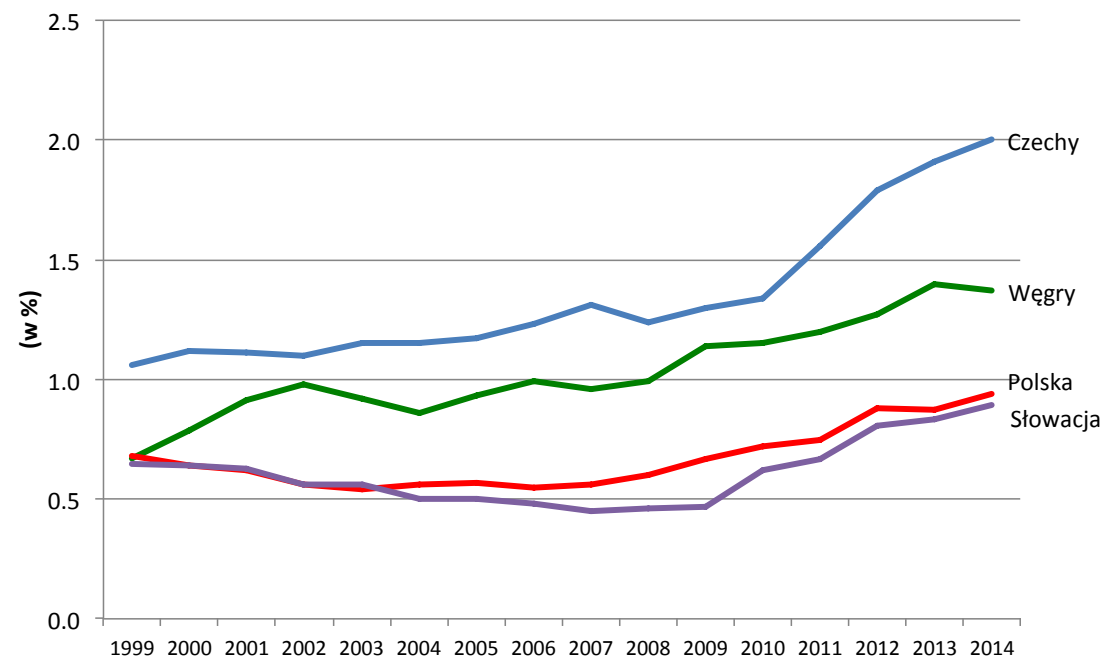

Rys 2. Wydatki na B+R (GERD) jako procent PKB w Polsce, Czechach, Słowacji i na Węgrzech

Źródło: opracowanie własne na podstawie danych Eurostat (stan na 1.06.2016 r.).

Skalę wzrostu wydatków na działalność B+R w Czechach wyraźnie widać w zestawieniu z Hiszpanią i Portugalią. Udział wydatków na B+R w Czechach stawia ten kraj na równi z Holandią oraz powyżej wyników notowanych w Hiszpanii, Portugalii, a nawet w Wielkiej Brytanii (rys. 3).

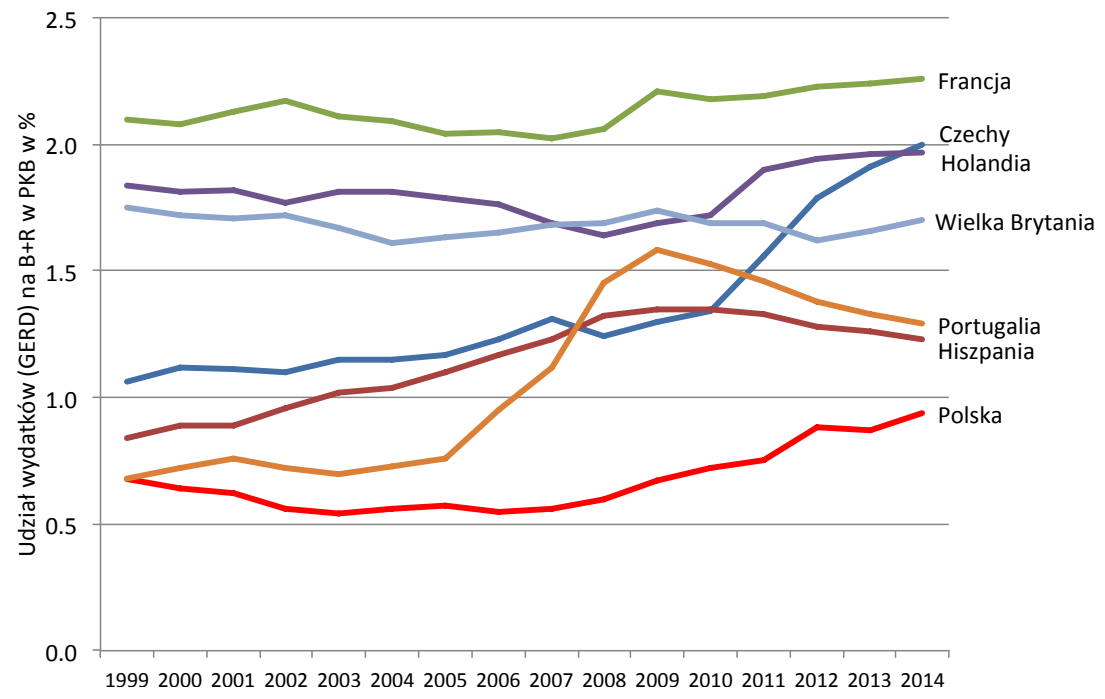

Rys. 3. Wydatki (GERD) na B+R w wybranych krajach Unii Europejskiej jako procent PKB

Źródło: opracowanie własne na podstawie danych Eurostat (stan na 1.06.2016 r.). 


\section{WYDATKI PRZEDSIĘBIORSTW NA DZIAŁALNOŚĆ BADAWCZO- -ROZWOJOWA}

Dynamiczny wzrost wydatków na działalność badawczo-rozwojową w Czechach, zwłaszcza $\mathrm{w}$ zestawieniu $\mathrm{z}$ wynikami pozostałych krajów grupy wyszehradzkiej jest wynikiem odmiennego podejścia do finansowania działalność badawczo-rozwojowej. W ciągu ostatniej dekady w Czechach stale spada udział przedsiębiorstw w finansowaniu działalności badawczo-rozwojowej (rys. 4). Jest to podejście odmienne od przyjętego w Polsce czy na Węgrzech, gdzie próby stymulowania zaangażowania przedsiębiorstw w finansowanie działalności badawczo-rozwojowej wydają się przynosić pierwsze efekty.

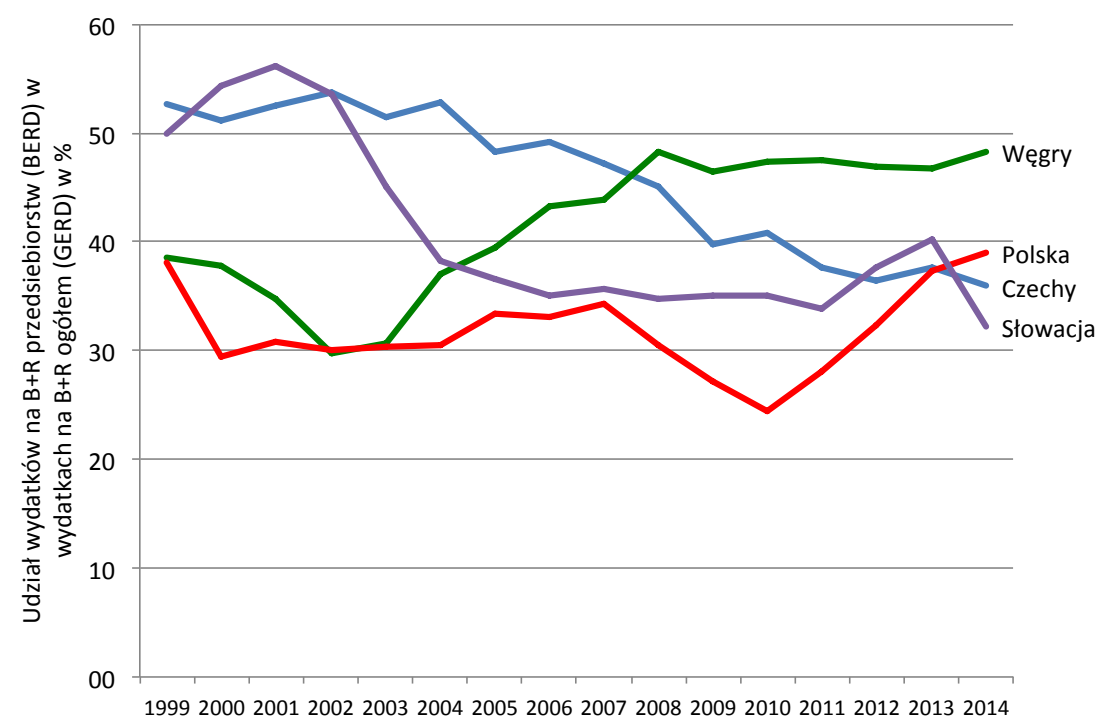

Rys. 4. Udział wydatków na $\mathrm{B}+\mathrm{R}$ przedsiębiorstw (BERD) w wydatkach na $\mathrm{B}+\mathrm{R}$ ogółem, w $\%$

Źródło: Opracowanie własne na podstawie danych Eurostat (stan na 1.06.2016 r.).

Działalność badawczo-rozwojowa realizowana w przedsiębiorstwach i finansowana przez przedsiębiorstwa może mieć charakter komercyjny, co przekłada się na oczekiwania dotyczące szybkiego wprowadzenia produktu na rynek. Przykładem tego typu oczekiwań jest Nylon wynaleziony w laboratoriach korporacji DuPont. Ocenia się, że na badania wydano 4 mln dolarów a przychody ze sprzedaży produktów i praw do technologii przez DuPont szacuje się na 25 mld dolarów przychodów (do czasu gdy w 2003 roku tę część korporacji sprzedano do Koch Industries) ${ }^{4}$.

Większość krajów Unii Europejskiej oraz Komisja Europejska zakładała cel zwiększenia udziału sektora przedsiębiorstw w finansowaniu działalności badawczo-rozwojowej. Powodów tego założenia należy szukać w:

1) dążeniach do zmniejszenia obciążenia budżetu państwa,

\footnotetext{
${ }^{4} \mathrm{~J}$. Lerner, The architecture of innovation: The economics of creative organizations, Harvard Business Press, 2012.
} 
2) większej aplikacyjności badań prowadzonych i finansowanych przez przedsiębiorstwa.

Gdy tworzono strategię lizbońską, struktura finansowania działalności badawczo-rozwojowej mogła się wydawać jednym z kluczowych czynników tworzących przewagę Stanów Zjednoczonych $w$ obszarze innowacji. W USA udział przedsiębiorstw w finansowaniu działalności badawczo-rozwojowej stanowił $69 \%$, w Japonii nawet $72 \%$, podczas gdy w Europie wynosił zaledwie 56\%. Wzrost udziału przedsiębiorstw przynajmniej do poziomu USA wydawał się oczywistym elementem w dążeniu do zwiększenia innowacyjności w gospodarkach krajów UE.

W tym samym czasie w Stanach Zjednoczonych dostrzegano wady i zagrożenia wynikające $\mathrm{z}$ dużego udziału przedsiębiorstw $\mathrm{w}$ finansowaniu działalności badawczo rozwojowej oraz problemy związane z mierzeniem tego zjawiska ${ }^{5}$.

Zwracano uwagę na:

- efekty wynikające ze zmian strategii przedsiębiorstw (zmiany w IBM lub DuPont) ${ }^{6}$,

- $\quad$ skutki przejęć (Nokia) i bankructw (Kodak) ${ }^{7}$,

- efekty outsourcingu produkcji (Apple),

- problem mierzenia zjawiska wynikający z faktu zatrudnienia naukowców poza działami badań i rozwoju (w zarządach, działach sprzedaży, marketingu, zaopatrzeniu lub produkcji).

W ostatnich latach w Stanach Zjednoczonych, Szwecji, Finlandii i Danii można zaobserwować spadek udziału finansowania działalności badawczo- rozwojowej przez przedsiębiorstwa (rys. 5). Podejście to przeczy założeniom Unii i celom większości krajów członkowskich. Powody tych zmian nie są do końca jasne. Ich przyczyn można doszukiwać się w skutkach kryzysu gospodarczego. Należy jednak zauważyć, że amerykanie od lat zwracali uwagę na słabnące zaangażowanie w badania podstawowe i postulowali wzrost finansowania rządowych ośrodków badawczych. Argumentacja uwzględniała założenie, że to właśnie badania podstawowe prowadzą do powstania przełomowych technologii, tworzących nie tylko nowe produkty, ale całe branże. Zaangażowanie środków publicznych w badania podstawowe można postrzegać jako uzupełnienie działań podejmowanych przez przedsiębiorstwa. Uwzględniając transfer technologii i interakcje uniwersytetów, ośrodków badawczych, instytucji otoczenia biznesu i przedsiębiorstw podejście równoważące rozwój we wszystkich obszarach może okazać się kluczem do sukcesu na poziomie kraju.

\footnotetext{
${ }^{5} \mathrm{P}$. Stephan, Using human resource data to illuminate innovation and research utilization [in:] S. Merrill, M. McGeary (Eds.), Using Human Resource Data to Track Innovation, Washington 2002.

${ }^{6}$ P.E. Stephan, Economics of Science [in:] B.H. Hall, N. Rosenberg (Eds.), Handbook of the

Economics..., p. 253.

${ }^{7}$ J. Lerner, The architecture...
} 


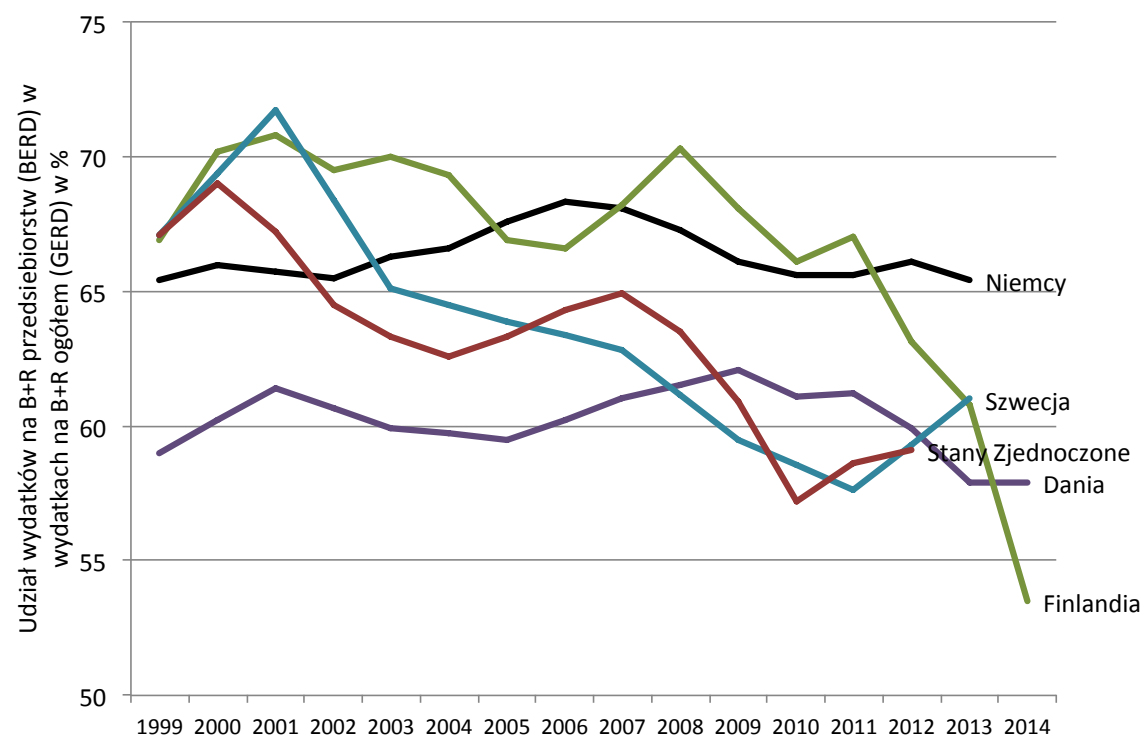

Rys. 5. Udział wydatków na B+R przedsiębiorstw (BERD) w wydatkach na B+R ogółem, w Szwecji, Danii, Finlandii, Niemczech i Stanach Zjednoczonych, w \%

Źródło: opracowanie własne na podstawie danych Eurostat (stan na 1.06.2016 r.).

Zmiany profilu działalności, fuzje i przejęcia oraz bankructwa przedsiębiorstw uwypuklają problem ciągłości działalności badawczo-rozwojowej w przedsiębiorstwach. $\mathrm{Z}$ punktu widzenia przedsiębiorstw zmiany są naturalne, a zamknięcie ośrodków badawczych nie szokuje w czasie restrukturyzacji, przekształceń, czy upadku. Należy zwrócić uwagę, że działalność badawczo-rozwojowa prowadzona w przedsiębiorstwach jest współfinansowana przez społeczność dotacjami i zwolnieniami podatkowymi. Kontynuacja działalności badawczo-rozwojowej jest więc w interesie społecznym, ale przedsiębiorstwa $\mathrm{w}$ długim okresie nie są najlepszym dysponentem aktywów $\mathrm{z}$ nią związanych.

Wnioski łączące wydatki na $\mathrm{B}+\mathrm{R}$ i wyniki finansowe przedsiębiorstw nie są jednoznaczne. Powiązanie działalności badawczo-rozwojowej, innowacyjności i rentowności czy tworzenia wartości postulowane w teorii nie znalazło jednoznacznego odzwierciedlenia w wynikach finansowych przedsiębiorstw ${ }^{8}$. Wydaje się, że wspomniane powiązania są uzależnione od wielu czynników wewnętrznych i zewnętrznych. Kryzys w 2008 roku miał w wielu przedsiębiorstwach znacznie większy wpływ na wyniki finansowe niż innowacyjność. Od lat finansowanie działalności $B+R$ jest krytykowane przez inwestorów nawet $\mathrm{w}$ branżach, $\mathrm{w}$ których nie tylko sukces, ale i przetrwanie zależne jest od innowacyjności. W ostatnich latach budżety na $\mathrm{B}+\mathrm{R}$ zmniejszono $\mathrm{w}$ wielu przedsiębiorstwach branży farmaceutycznej (rys. 6). Wiele firm stworzyło otwarte

\footnotetext{
${ }^{8} \mathrm{G}$. Dosi, Statistical regularities in the evolution of industries. A guide through some evidence and challenges for the theory [in:] F. Malerba, S. Brusoni (Eds.), Perspectives on Innovation, Cambridge University Press, Cambridge 2007.
} 
systemy $\mathrm{B}+\mathrm{R}$ oraz innowacji ${ }^{9}$ i zmniejszyło wydatki na B+R (Pfizer, Merck US i Roche) w innych wzrost wydatków należy uznać za spektakularny (Volkswagen i Samsung Electronics).

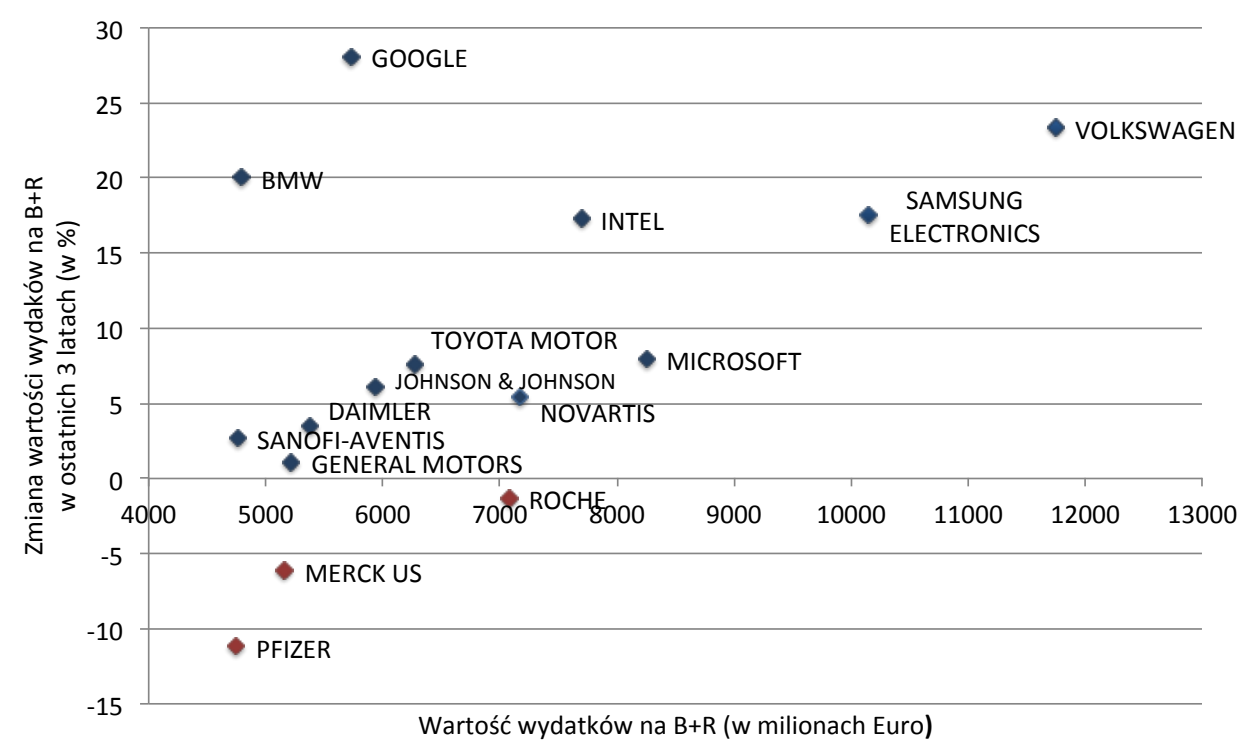

Rys. 6. 15 korporacji ponoszących najwyższe wydatki na działalność badawczo-rozwojową w 2014 roku

Źródło: opracowanie własne. Dane projektu The Economics of Industrial Research \& Innovation realizowanego przez Institute for Prospective Technological Studies.

\section{ZMIANY W OTOCZENIU BIZNESU}

Wiele badań wskazuje na duże znaczenie formalnego i nieformalnego transferu technologii $\mathrm{z}$ uniwersytetów do przedsiębiorstw ${ }^{10}$. Uniwersytety nie powstały po to, aby prowadzić badania naukowe, ale by spełniać inne role na rzecz rozwoju społecznego ${ }^{11}$. Obecnie przechodzą zmiany coraz mocniej angażując się $\mathrm{w}$ badania o charakterze komercyjnym i świadcząc usługi dla przedsiębiorstw.

W krajach Unii w ciągu dekady powstało wiele organizacji lokalnych, regionalnych i krajowych, których celem jest wspieranie transferu technologii, przedsiębiorczości i innowacyjności przedsiębiorstw.

\footnotetext{
${ }^{9}$ E. Enkel, O. Gassmann, H. Chesbrough, Open $R \& D$ and open innovation: exploring the phenomenon, "R\&D Management" 2009, 39(4), p. 311-316.

${ }^{10}$ R.J. Blażlak, K. Owczarek, Modele transferu technologii, Łódź 2013; W. Cohen, R.R. Nelson, J.P. Walsh, Links and impacts: The influence of public research on industrial $R \& D$, "Management Science" 2002, 48 (1), p. 1-23.

${ }^{11}$ W. Czakon, Przemyst badań naukowych. Implikacje dla interpretatywnych metod w naukach o zarzadzaniu, „Organizacja i Kierowanie” 2015, nr 4(169), s. 101-114.
} 
Ocenia się, że do 2013 roku w UE powstało 366 parków naukowo-technologicznych, w których działalność prowadziło ponad 40000 przedsiębiorstw ${ }^{12}$. Szacuje się, że w powstanie oraz rozwój parków naukowo-technologicznych zainwestowano $12 \mathrm{mld}$ euro.

\section{ZAKOŃCZENIE}

W latach 2010-2014 udział wydatków na B+R w PKB Unii Europejskiej stale wzrastał. W poszczególnych krajach Unii podejście do finansowania działalności $\mathrm{B}+\mathrm{R}$ było zróżnicowane. Różnice widoczne są zarówno w dynamice wzrostu, jak i w strukturze jego finansowania. W niektórych krajach preferowany jest wzrost finansowania ze środków państwowych w innych, w tym w Polsce, stymuluje się wzrost wydatków przedsiębiorstw na działalność $B+R$. Zastanawiający jest spadek udziału przedsiębiorstw w finansowaniu działalności B+R w Stanach Zjednoczonych, Szwecji, Finlandii i Danii. Zmiany $\mathrm{w}$ sposobie finansowania działalności badawczo-rozwojowej powinny być obserwowane przez zarządzających przedsiębiorstwami ponieważ odmienne podejście do sposobu finansowania działalności badawczo-rozwojowej na poziomie kraju powinno zostać uwzględnione w ich analizach i decyzjach. Władze lokalne, regionalne i krajowe powinny monitorować czy inwestowanie publicznych pieniędzy w postaci dotacji ze środków UE i zwolnień podatkowych przynosi oczekiwane korzyści.

\section{LITERATURA}

[1] Blażlak R.J., Owczarek K., Modele transferu technologii, Wydawnictwo Politechniki Łódzkiej, Łódź 2013.

[2] Cohen W., Nelson R.R, Walsh J.P., Links and impacts: The influence of public research on industrial $R \& D$, "Management Science" 2002, 48 (1), p. 1-23.

[3] Czakon W., Przemyst badań naukowych. Implikacje dla interpretatywnych metod w naukach o zarzadzaniu, „Organizacja i Kierowanie” 2015, nr 4(169), s. 101114.

[4] Dosi G., Statistical regularities in the evolution of industries. A guide through some evidence and challenges for the theory [in:] F. Malerba, S. Brusoni (Eds.), Perspectives on Innovation, Cambridge University Press, Cambridge 2007.

[5] Enkel E., Gassmann O., Chesbrough H., Open $R \& D$ and open innovation: exploring the phenomenon, "R\&D Management" 2009, 39(4), p. 311-316.

[6] Europa 2020, Strategia na rzecz inteligentnego i zrównoważonego rozwoju sprzyjajaca właczeniu społecznemu, ec.europa.eu/eu2020/pdf/1_PL_ACT _part1_v1.pdf

[7] European Commission, 2014, Setting up, managing and evaluating EU science and technology parks, Publications Office of the European Union.

[8] Hall B.H., Rosenberg N. (Eds.), Handbook of the Economics of Innovation (Vol. 1), Elsevier 2010.

[9] Lerner J., The architecture of innovation: The economics of creative organizations, Harvard Business Press 2012.

\footnotetext{
${ }^{12}$ European Commission, Setting up, managing and evaluating EU science and technology parks, Publications Office of the European Union 2014, 2.
} 
[10] Stephan P.E., Using human resource data to illuminate innovation and research utilization [in:] S. Merrill, M. McGeary (Eds.), Using Human Resource Data to Track Innovation, National Academy Press, Washington 2002.

[11] Stephan P.E., Economics of Science [in:] B.H. Hall, N. Rosenberg (Eds.), Handbook of the Economics of Innovation (Vol. 1). Elsevier 2010.

CHANGES IN R\&D EXPENDITURE IN EU COUNTRIES AND BUSINESSES

In many fields of science and branches of economy research and development expenditure determines the scale and quality of research. Research and development expenditure is determined by national policies, corporate strategies and by investors. The aim of this paper is to present the changes in research and development expenditure in European Union countries and companies in the years 2010-2014. The analysis encompasses the starting point for Europe 2020 strategy and the period in which Lisbon strategy was implemented. Results indicate changes and surprising variety in approach to research and development financing both in countries and businesses. The differences can be observed in growth and financing structure. They cannot, however, be explained by grouping the countries according to the criteria of country's GDP or R\&D expenditure. Interesting differences can be observed in Visegrad group countries in which the relation of $R \& D$ expenditure to GDP is changing dynamically. In some countries government expenditure is preferred in others, including Poland, business expenditure on R\&D are stimulated. While it is difficult to draw conclusions as to which route is better for national economies and businesses the impact of national policies seems to be visible in statistics. The changes in financing of research and development expenditure should be observed and taken into account in managerial analyses and decisions.

Keywords: research, development, expenditures, business, Europe.

DOI:10.7862/rz.2017.hss.12

Przesłano do redakcji: styczeń 2017 r.

Przyjęto do druku: marzec 2017 r. 
